\title{
THAI ELDERLY WHO DO NOT CORESIDE WITH THEIR CHILDREN
}

\begin{abstract}
In this paper, data from a nationally representative survey of elderly Thais living in private households are analyzed. The analysis focuses on situations of the 756 elderly who do not coreside with an adult child. Only a minority of those elderly who do not coreside with an adult child were childless. The majority have at least one noncoresident child with whom they could potentially live. Daily contact with children for elderly who live alone was not significantly different from that of elderly who live with their children, suggesting that households that are classified as being separate may in fact function as single households or that at least one non-coresident child may live in very close proximity to the elderly person. Differences between urban and rural elderly in terms of type of support received from non-coresident children as well as likelihood of living near a non-coresident child are discussed.
\end{abstract}

Key Words: elderly, Thailand, living arrangements, family support

\section{INTRODUCTION}

In Thailand as elsewhere in Asia, responsibility for the support and care of the elderly in both a normative and practical sense rests largely with the family and within the family, primarily with the children. A recent survey of rural adults in two different regions of Thailand indicates virtually universal agreement that "it is the children's responsibility to take care of their parents when the parents get old" (Wongsith 1990). This familial care system typically involves coresidence of the elderly members with at least one child (Cowgill 1972; Pramualratana 1990; Tuchrello 1989; Knodel, Saengtienchai, and Sittitrai 1992; Caffrey 1992a and 1992b; Hashimoto, Kendig, and Coppard 1992). Indeed, coresidence with an adult child is probably the most crucial aspect of the familial system of support and assistance as it currently exists in Thailand. No other arrangement is likely to be able to meet the wide ranging needs of the elderly as fully as shared residence in a household with adult children (Sung 1991). Nevertheless, as the present study shows, most of the minority who do not live with an adult child appear to be in situations in which the familial support system still operates.

There is ample evidence to document the predominance of coresidence as both the preferred and actual living arrangement during old age in Thailand. Results of a national and a quasi-national survey conducted in 1986 and 1990 respectively both indicate that $77 \%$ of the population aged 60 and over live with children (Knodel, Chayovan, and Siriboon 1992; Andrews and Hennink 1992). Despite these high levels of coresidence, a substantial minority of Thai elderly do not reside with children. This minority includes not only childless elderly but also those whose children all live away from the parental household. Rubinstein (1987) has recently called attention to the lack of research on childless elderly. 
This group is of particular interest in societies where the indigenous social system for support and care of the elderly typically rests with the adult children.

Equally of interest are elderly parents who do not coreside with children in countries such as Thailand where coresidence is the clear norm. There is a similar dearth of research on this group. The present study focuses on the characteristics and living arrangements of Thai elderly who do not live with children, including both the childless and those whose children are all noncoresident. For convenience, the term 'non-coresident elderly' in the present text specifically refers to this group of elderly who do not coreside with a child of their own, regardless of whether or not the elderly individual is living with persons other than one of his or her own children and including all childless elderly. The term 'elderly parents' is used to distinguish elderly with living children (including step and adopted children) from those who have none.

Data for the present study come from a nationally representative survey of elderly in private households conducted in 1986 as part of a project entitled Socio-economic Consequences of the Aging Population in Thailand (SECAPT). The project was carried out by the Institute of Population Studies, Chulalongkorn University as part of the ASEAN Population Program. Following the usual definition of elderly used in Thailand, the survey focused on respondents aged 60 and over. In total, 3,252 elderly respondents were successfully interviewed. ${ }^{1}$ Much of the following analysis is based on the subset of 756 elderly who did not coreside with one or more of their children. In addition, limited reference is made to qualitative data collected during 1990 and 1991 by the Institute of Population Studies through a series of focus group discussions with Thai elderly and their adult children throughout Thailand (Knodel, Saengtienchai, and Sittitrai 1992).

\section{LIVING ARRANGEMENTS}

As Table I shows, $77 \%$ of Thai elderly interviewed in the 1986 SECAPT sample were living with one or more children. ${ }^{2}$ No difference in the prevalence of coresidence is evident between rural and urban elderly or between elderly men and women. A moderate inverse association is apparent, however, between age of the elderly and likelihood of coresidence, largely reflecting life course effects of the children: as elderly age, so do their children, thus increasing the probability that a child will move out of the parental household (Knodel, Chayovan, and Siriboon 1993). Nevertheless, even among Thais aged 75 and older, over $70 \%$ live with at least one child, reflecting the traditional arrangement whereby one child remains to care for the parents. Very few of the current generation of elderly (only 4\%) have no living child (including step and adopted children). Thus even among elderly who do not coreside with a child, only a minority were childless. Regardless of residence, gender or age, the large majority of noncoresident elderly had at least one child with whom they potentially could have coresided.

Since the SECAPT survey included a listing of all members of each sample 
TABLE I

Percent distribution of Thai elderly population (age 60+) according to coresidence and childlessness status by place of residence, gender and age of elderly

\begin{tabular}{|c|c|c|c|c|c|}
\hline & & $\begin{array}{r}\% \text { Not livi } \\
\text { chil }\end{array}$ & with & & \\
\hline & $\begin{array}{l}\% \text { living } \\
\text { with child }\end{array}$ & Childless & Has child & $\begin{array}{l}\text { Total } \\
\text { percent* }\end{array}$ & $\begin{array}{l}\mathrm{N} \text { of cases } \\
\text { (unweighted) }\end{array}$ \\
\hline Total elderly & 77 & 4 & 20 & 100 & 3,245 \\
\hline $\begin{array}{c}\text { Residence } \\
\text { Urban } \\
\text { Rural }\end{array}$ & $\begin{array}{l}77 \\
77\end{array}$ & $\begin{array}{l}6 \\
3\end{array}$ & $\begin{array}{l}17 \\
20\end{array}$ & $\begin{array}{l}100 \\
100\end{array}$ & $\begin{array}{r}826 \\
2,419\end{array}$ \\
\hline $\begin{array}{l}\text { Gender } \\
\text { Male } \\
\text { Female }\end{array}$ & $\begin{array}{l}77 \\
77\end{array}$ & $\begin{array}{l}3 \\
4\end{array}$ & $\begin{array}{l}20 \\
19\end{array}$ & $\begin{array}{l}100 \\
100\end{array}$ & $\begin{array}{l}1,328 \\
1,917\end{array}$ \\
\hline $\begin{array}{l}\text { Age } \\
\qquad \begin{array}{l}60-64 \\
65-69 \\
70-74 \\
75+\end{array}\end{array}$ & $\begin{array}{l}81 \\
77 \\
74 \\
72\end{array}$ & $\begin{array}{l}3 \\
4 \\
4 \\
3\end{array}$ & $\begin{array}{l}15 \\
19 \\
23 \\
24\end{array}$ & $\begin{array}{l}100 \\
100 \\
100 \\
100\end{array}$ & $\begin{array}{r}1,079 \\
877 \\
593 \\
696\end{array}$ \\
\hline
\end{tabular}

Note: Children include step and adopted children.

* = Percentages may not total to 100 due to rounding.

Source: 1986 SECAPT Survey.

household, including information on relationship to head, it is possible to examine the living arrangements of those elderly who were not coresiding with one of their own children. One complication in determining the household composition, however, arises from the fact that the same Thai word (laan) is used to refer to a grandchild, nephew or niece, thus making it difficult to distinguish between them. Moreover, the term is sometimes used generically for younger relatives and thus on occasion encompasses more distant relatives of the younger generation. Despite this limitation, information on age and occupation that was also included in the household listing can be used roughly to distinguish cases where a younger generation relative was likely a dependent in the household from cases where he or she was able to contribute economically to the household and/or provide care-giving services for the elderly members.

Several indicators of living arrangements of non-coresident elderly are presented in Table II. The results make clear that elderly who do not live with their own children live in a diverse set of household situations. Slightly less than a fifth (18.8\%) live in solitary (i.e., one person) households. Just over half of non-coresident elderly live with a spouse, although in many cases the couple are living by themselves. ${ }^{3}$ If the almost $30 \%$ who live only with a spouse is combined with elderly in solitary households, we see that just under half of Thai elderly who do not coreside with a child live on their own while slightly more than half live with other household members. Overall, almost half of non- 
TABLE II

Indicators of living arrangements among Thai elderly not coresiding with a child, by childlessness status

\begin{tabular}{llll}
\hline & \multicolumn{3}{l}{ Elderly not living with children } \\
\cline { 2 - 4 } & All & Childless & Has a child \\
\hline \% live alone & 18.8 & 13.4 & 19.8 \\
\% live with spouse & 52.1 & 28.8 & 56.3 \\
$\quad$ \% live with spouse only & 29.5 & 19.8 & 31.3 \\
\% live with child-in-law & 1.6 & 1.0 & 1.7 \\
\% live with 'laan' & 46.0 & 53.1 & 44.7 \\
- \% live with economically & & & \\
$\quad$ active 'laan' & 25.4 & 42.7 & 22.3 \\
- \% live with 'laan' age 18+ & 24.7 & 47.6 & 20.6 \\
\% live with any other person & 21.8 & 54.0 & 16.0 \\
N of cases (unweighted) & 753 & 120 & 633 \\
\hline
\end{tabular}

Note: Except for 'live alone' and 'live with spouse only' the categories shown are not mutually exclusive and thus the percentages do not add to 100 .

Source: 1986 SECAPT Survey.

coresident Thai elderly live with either a laan or child-in-law, primarily the former. Thus in the vast majority of cases where other household members are present, at least one is a younger generation relative. In some of these cases the younger relative is either economically active or an adult or both, while in others he/she may be a dependent, often a grandchild being cared for on a long term basis by the elderly person or couple. ${ }^{4}$

Results in Table II also indicate some differences between the living arrangements of childless elderly and those of non-coresident elderly parents. Childless elderly are less likely to live in solitary households and much less likely to live with a spouse (reflecting the substantial proportion among the childless who never married or whose marriage ended prematurely) but are much more likely to live with persons other than younger generation relatives (e.g., siblings). Moreover, childless elderly are not only more likely than non-coresident elderly parents to live with a younger generation relative but when they do, the younger generation relative is much more likely to be an adult or be economically active.

The fact that the majority of elderly with no children are incorporated into households with other family members and in many cases live with an economically active or adult younger generation relative (presumably typically a niece or nephew) suggests that even for childless elderly, the familial system of care operates in Thailand. That the norm is for the family to be responsible even for childless elderly is confirmed by some focus group participants.

Moderator: If you have no children when you are old, on whom can you depend?

Ms. Tui: Are there siblings? Siblings won't desert us ... If the siblings are good, they won't abandon each other.

[Central rural elderly focus group participant] 
Ms. Pim: If (old people) don't have children, they will have brothers and sisters who have children. They expect to depend on one of them... If we can't depend on relatives, on whom can we depend?

[Central rural adult focus group participant]

The impression that the family takes care of childless elderly merits some qualification in light of the fact that the SECAPT survey excluded elderly in collective households and that childless elderly are likely disproportionately represented among collective households. Results from the 1980 census indicates that only $1.7 \%$ of the Thai population aged 60 and over live in such households, primarily in temples where presumably they are Buddhist monks or nuns (Chayovan, Knodel, and Siriboon 1990). Virtually no elderly reside in nursing homes or special homes for the elderly (Pichyangkura and Singhajend 1991).

\section{LOCATION AND CONTACT WITH NON-CORESIDENT CHILDREN}

There is also evidence from the SECAPT survey that most non-coresident elderly parents are not isolated from their children and indeed in many cases are very much part of a familial support system in which their children play a central role. In interpreting the statistical finding that $20 \%$ of elderly parents reside apart from their children, it is important to understand that the official definition of a household and hence coresidence as used in most surveys in Thailand and elsewhere is typically rather narrow. Surveys such as SECAPT usually treat dwelling units with separate addresses (house numbers) as separate households in accordance with the government's household registration system. Indeed respondents are likely to think in similar terms when asked who the members of the household are given the importance of household registration forms for most interactions with the state bureaucracy. 5

Such a technical definition does not always take into account situations where elderly parents and children live in separate dwellings but within a common cluster of houses that are in fact interdependent to substantial degrees. ${ }^{6}$ Such an arrangement is not unusual, especially in rural areas (Cowgill 1972; Tuchrello 1989). Thus indices of coresidence narrowly defined as living together within the same officially designated household (i.e., dwelling unit) do not fully capture the extent to which the living arrangements of elderly and their families are intertwined.

While the SECAPT survey does not reveal whether the respondent lived in a house adjacent to or very near a child, it does show whether or not non-resident children lived in the same locality (defined in rural areas as the same village, in provincial urban areas as the same town, and in Bangkok as the same district). Moreover, some indication of the prevalence of arrangements whereby noncoresident children live near enough to serve some of the functions that a coresident child might fulfill can be gained from responses to questions on the frequency of contact that elderly have with non-coresident children. 
SIRIWAN SIRIBOON AND JOHN KNODEL

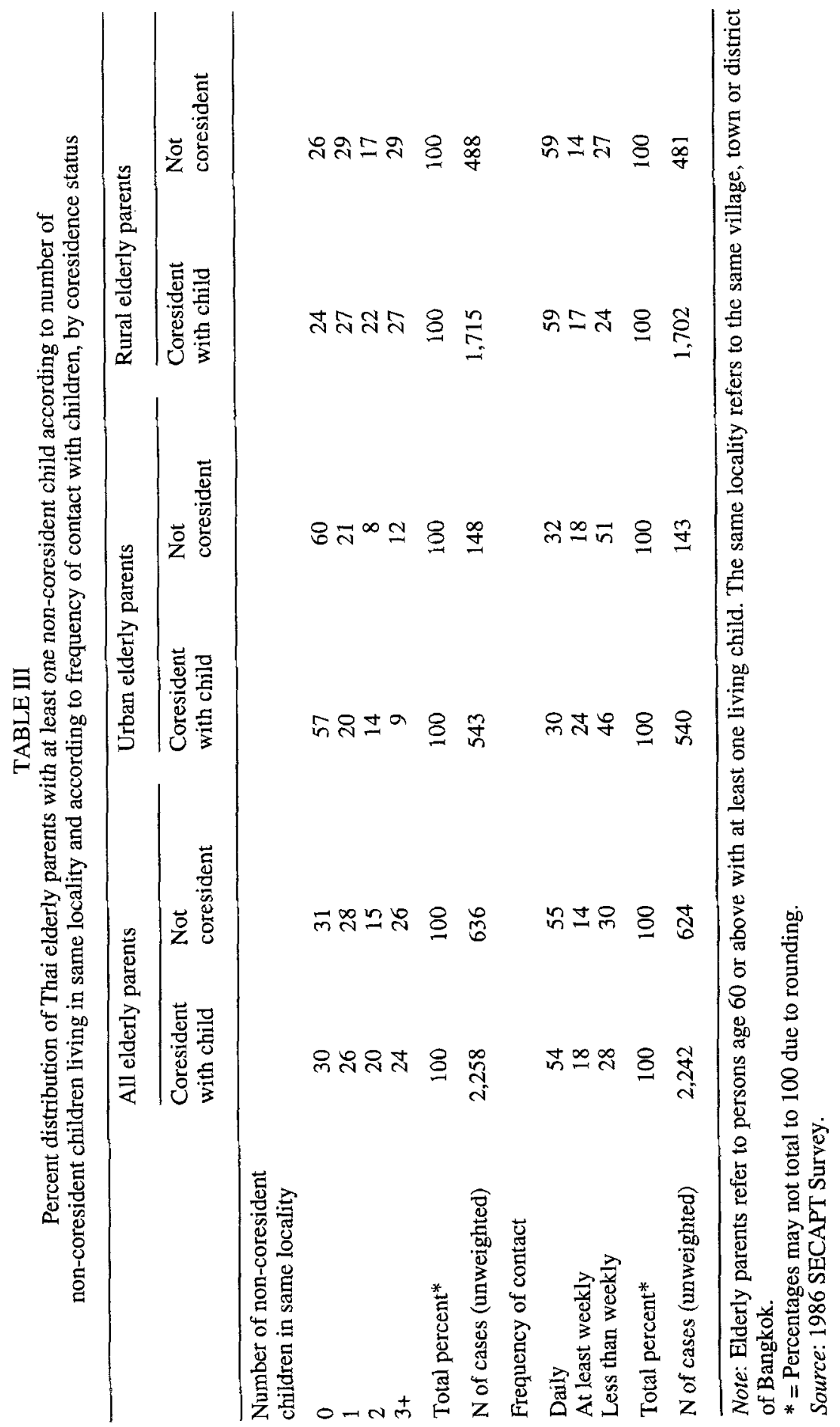


Results in Table III indicate that among elderly parents who have at least one non-coresident child, a substantial majority of both those who live with a child and those who do not live with a child (70\% and $69 \%$ respectively) have at least one non-coresident child who lives in the same locality and approximately a fourth of both groups have three or more children in their locality. ${ }^{7}$ This is far less common among urban elderly than rural elderly, however, probably because children of rural elderly are more likely to farm for a living and thus remain in the parental village where the family land is typically located, while few children of the urban elderly are likely to have occupations that tie them directly to the local area. ${ }^{8}$ Moreover, higher housing costs and lesser availability of land in urban areas may encourage urban adult children to remain in the parental household longer if they stay in the same locality rather than forming a satellite household nearby. Note that overall, coresidence of elderly with children is slightly higher in urban than in rural areas (Knodel, Chayovan and Siriboon 1992).

Information collected in the SECAPT survey on the frequency of contact with non-coresident children reveals elderly parents commonly have daily contact with at least one non-coresident child. Overall, more than half (54\%) of elderly with non-coresident children see at least one such child daily, and nearly threefourths of those with a non-coresident child in the same locality have daily contact (Knodel, Chayovan, and Siriboon 1992). The bottom panel of Table III compares the frequency of contact with non-coresident children according to the coresidence status of elderly parents with at least one non-coresident child. There is little difference in this respect between coresident and non-coresident parents. However, daily contact with a non-coresident child is almost twice as common among rural elderly as it is among urban elderly regardless of coresidence status of the parents. This difference reflects in large part the ruralurban difference in the proportion of elderly with a non-coresident child in the same locality.

Such daily contact no doubt reflects a close proximity of residences and affords nearby adult children the opportunity to provide a variety of services to the elderly parent (and vice versa). In some cases there may be little qualitative difference in the nature of support received from children by elderly parents who coreside in the same dwelling unit and elderly who appear to live in separate households but are in daily contact with one or more adult children. More to the point of the present analysis, in cases of non-coresident elderly parents, the daily contact may reflect a relationship with a nearby child that functions in a manner similar to the relationship between elderly and their coresident children.

\section{MATERIAL SUPPORT FROM NON-CORESIDENT CHILDREN}

While the above results make clear that the frequency of contact with noncoresident children does not differ by coresidence status, the extent and nature of exchanges between parents and non-coresident children might differ. It is interesting to consider whether such support provided by non-coresident 
children might be more extensive in cases where the elderly parent does not live with a child, thus compensating for the absence of a coresident child in the elderly's household. Material support from children outside the household might well be particularly critical for the parents' well-being in cases where the parents are not living with others who help in the upkeep of the household. In the SECAPT survey, respondents were asked whether or not each of their children had ever provided regular support and if so, what kind of support was provided during the past year. ${ }^{9}$ Given the open-ended nature of the question and lack of systematic probes about types of support not spontaneously mentioned, the results are likely to understate the extent to which non-coresident children provide such support to their parents. Nevertheless, the information should serve as a rough indication of material assistance from children outside the immediate household.

Two types of material support from non-coresident children can be distinguished from the SECAPT data: the provision of food and/or clothes and the provision of money. ${ }^{10}$ As shown in Table IV, over two thirds $(69 \%)$ of noncoresident elderly parents indicated that they receive regular support in the form of food and/or clothes from non-coresident children, and only a slightly lower proportion $(58 \%)$ indicated that non-coresident children provided money on a regular basis. In both cases this is somewhat higher than the proportion of coresident elderly parents who received such support, although the differences are not large, especially if only coresident elderly parents with at least one noncoresident child are considered. The mean number of non-coresident children contributing these two types of material support also is greater for non-coresident parents than for coresident parents. Again the differences are moderate.

Patterns of differences between coresident and non-coresident elderly parents with respect to the indicators of material support in Table IV are similar for urban and rural areas. Moreover, there is little difference between rural and urban elderly with respect to receiving money from children living outside the household. Rural elderly, however, are almost twice as likely as those in urban areas to regularly receive food and/or clothes from non-coresident children. This undoubtedly reflects the greater availability of nearby non-coresident children in rural areas, as indicated by Table III, since food and/or clothing are typically provided by nearby children (as opposed to those living outside the locality). In contrast, money is more likely to be provided by children who reside further away (Knodel, Chayovan, and Siriboon 1993). Moreover, in urban areas, money takes on an even greater importance than in rural areas.

The survey results indicate that non-coresident parents are more likely to receive material support from children outside the household than elderly who live with children. This may be a response to greater need when no coresident child is present or, put in a different way, a reduced sense of responsibility on the part of non-coresident children when the elderly parent lives with another child. However, the magnitude of the difference is at most quite moderate. Within Thai culture non-resident children are expected to make at least some contribution (whether substantial or only symbolic) to their elderly parents even 
THAI ELDERLY

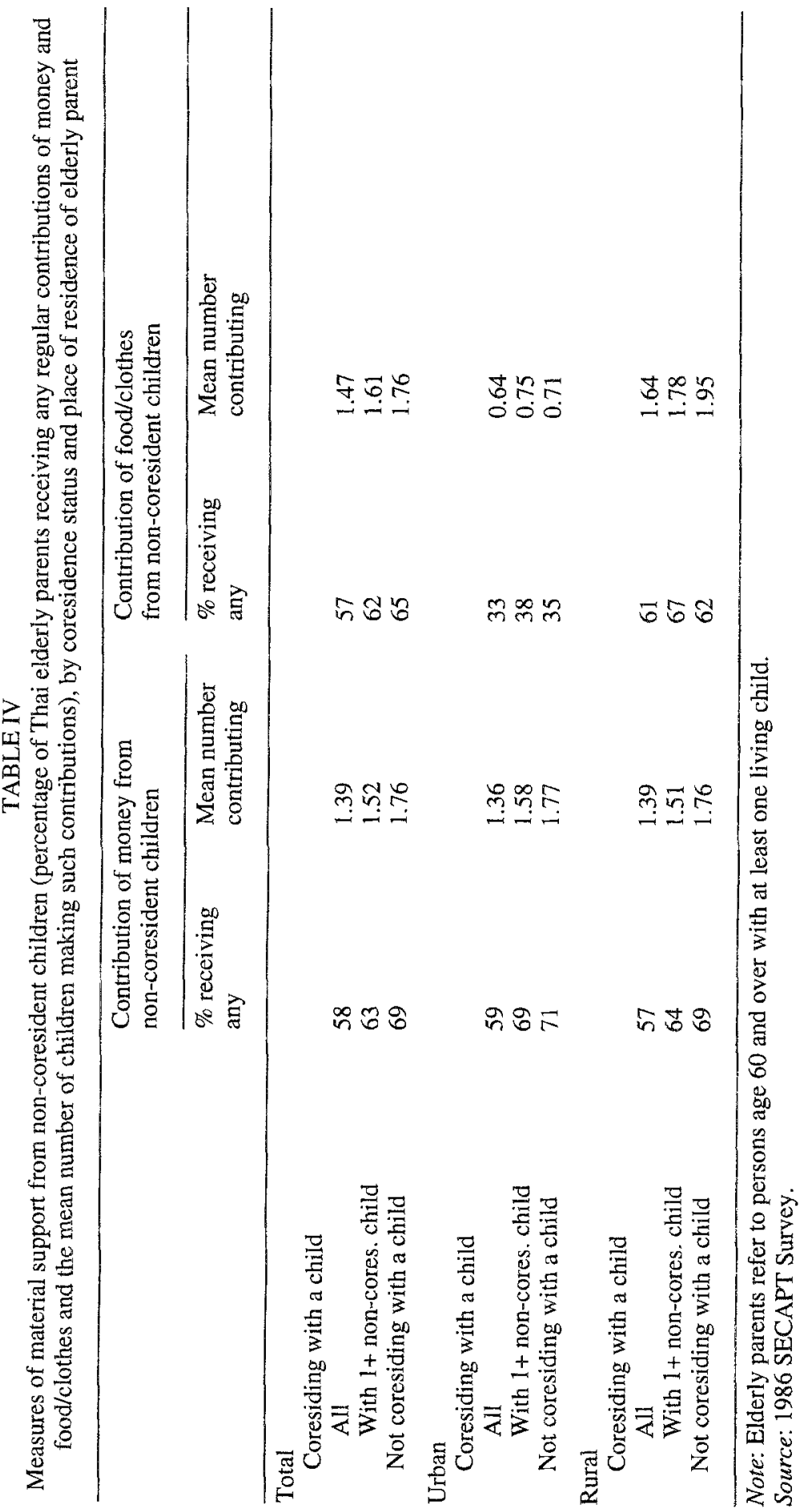


when the parents coreside with a sibling, as the focus group participants make clear.

Ms. Khumnai: Nowadays, if there are many brothers and sisters and the mother is left with one, the others must support that one financially.

[Bangkok slum adult focus group participant]

Anonymous (Female): Mostly those who live far away from parents will give them some (money).

Many: Children who are with them don't give them money since they provide them food every day.

Mr. Ubol: In case of money, it must be those who are away from them since those who are with them feed them regularly.

[Bangkok slum adult focus group participant]

Ms. Kloy: If the children are far away, they come to see us once in a long while. But if they are near us, they tend to send us food and sometimes money quite often.

[Central rural elderly focus group participant]

The lack of a substantial difference between those elderly parents who coreside with children and those who do not in the receipt of any material support from non-coresident children may be more a reflection of the general norm that all children should help support elderly parents than a sign of failure to respond to need. Perhaps if more complete information were available about the amount and frequency of material support received, more pronounced differences would be evident.

\section{PERSONAL PROBLEMS}

Given the normative preference for living with children among Thai elderly, it is of interest to examine whether the absence of children affects the elderly person's sense of emotional and material well being. The SECAPT survey included several questions about specific personal problems that should reveal the elderly's satisfaction with their living arrangements, including whether the respondent had a problem regarding insufficient money, poor housing, feelings of loneliness, or feelings of being unwanted. If elderly parents who are not coresident with children have been rejected or deserted by their children or if childless elderly have been left out of the normatively prescribed support system, we might expect that they would suffer more from these problems.

Table $\mathrm{V}$ indicates the extent to which the various personal problems itemized above were reported by elderly according to their coresidence and childless status. The perceived severity of each problem is judged by whether the elderly respondent considered a particular issue a personal problem and if so, how much of one. A mean severity score has been calculated assigning a value of 0 if the respondent said the issue was no problem, 1 if it was somewhat of a problem and 2 if it were very much a problem. Overall, there is little apparent difference between coresident elderly and either non-coresident elderly parents or childless elderly with respect to severity score for any of the four issues. These results 
TABLE V

Mean severity score of selected personal problems among Thai elderly, by coresidence and childlessness status

\begin{tabular}{|c|c|c|c|c|}
\hline & \multirow{2}{*}{$\begin{array}{l}\text { Elderly } \\
\text { coresident } \\
\text { with child }\end{array}$} & \multicolumn{3}{|c|}{ Elderly not coresident with child } \\
\hline & & Total & Childless & Has a child \\
\hline \multicolumn{5}{|l|}{$\begin{array}{l}\text { Mean severity score } \\
\text { of problems regarding }\end{array}$} \\
\hline Insufficient money & 0.8 & 0.7 & 0.9 & 0.7 \\
\hline Poor housing & 1.4 & 1.4 & 1.5 & 1.3 \\
\hline Feeling lonely & 1.2 & 1.1 & 1.1 & 1.1 \\
\hline Feeling unwanted & 1.5 & 1.4 & 1.4 & 1.4 \\
\hline $\mathrm{N}$ of cases (unweighted) & 2,431 & 737 & 622 & 115 \\
\hline
\end{tabular}

Note: Severity score is 0 if the respondent indicated that the issue was not a problem personally, 1 if the issue was somewhat of a problem, and 2 if the issue was a serious problem. Respondents who were not sure or did not answer are excluded.

Source: 1986 SECAPT Survey.

suggest that non-resident elderly do not live in particularly adverse circumstances or feel especially deserted or ignored.

Quite possibly, in the Thai cultural context where family responsibility is so widely accepted, especially with respect to the obligations of children, elderly who reside separately from children are self-selected for those who can do so without serious difficulties. For example, the non-coresident group may be disproportionately concentrated among elderly who live next to children, have their own means of livelihood, and are in reasonably good health. Indeed, living separately, while not the norm, is not always viewed negatively in Thailand, especially if children are nearby. As the focus group discussions made clear, some elderly prefer this situation.

Mr. Bunsong: If we live by ourselves, our children should live nearby... We don't want to live in the same house as our children and grandchildren. It's very noisy and hectic... Living near our children gives us a warm feeling.

Ms. Jua: I prefer to live in a different house but close to theirs.

Ms. Rumpung: For me, I want to live in a small house surrounded by my children's houses.

[Bangkok slum elderly focus group participant]

Ms. Tumma: I want (my children) to support me but I don't want to be in the same house ... But they must support us. In that case, it's alright since it's like being in the same family. Only that we live in our house ... We feel more at ease that way. No one bothers us ... We are by ourselves. They prepare us meals ... but they do not interfere much with us....

Mr. Chanha: Let me explain. We want peace. In the big house, when many people gather to drink, it's very noisy. We don't like it since we want to live quietly. I don't like a noisy atmosphere. 
[Northeastern rural elderly focus group participant]

Mr. Charoew: Living which children causes problems. If possible, I prefer to live only with my wife. What I seek is peacefulness, not money ... (The children) are next to us.

[Southern rural elderly focus gruop participant]

If and when the conditions change which make living apart seem satisfactory, living arrangements might also be altered. This does not mean that no Thai elderly are neglected by their children or close kin but suggests that they are rare enough that their existence does not outweigh the more positive situations of others who are 'allowed' to live separately. Moreover, the mere fact of coresidence does not necessarily signal that all needs of the elderly parents are being met nor that the relationships with the coresident children are satisfactory.

\section{DISCUSSION}

The evidence presented above suggests that many Thai elderly who do not live with children of their own are nevertheless in living arrangements that can be construed as consistent with the prevailing normative mandate assigning family responsibility for support and care of the elderly. Using information available in the SECAPT Survey, it is possible to divide non-coresident Thai elderly into categories that might be assumed to reflect different levels of integration into the general familial system of support and exchange, as illustrated in Table VI. The categories shown have been determined in an hierarchical manner such that each prior category takes precedence over each subsequent one.

Since having daily contact with one or more of one's own children implies living quite nearby and seems to resemble most closely the traditional form of coresidence, this category is given precedence over all other categories of living arrangements shown. In some cases, daily contact may reflect circumstances that for all practical purposes are the same as coresidence but have not been defined as such because of the technicalities of the household registration system. Over four fifths $(82 \%)$ of non-coresident elderly parents who report daily contact with a child also report receiving food and/or clothes regularly which is almost twice as great as for non-coresident elderly parents who do not report daily contact (results not shown).

Almost half of the non-coresident Thai elderly overall and more than half of those with children have daily contact with a child. Differences are not pronounced according to gender of the elderly respondent but are substantial by residence. As noted above, daily contact is far more common among rural than urban elderly, reflecting differences in the availability of children living nearby. Older non-coresident elderly (aged 70+) are also more likely to see one of their children daily than those aged 60 to 69 . This latter difference may reflect a greater need for contact (and care) as health deteriorates with age.

Living with an economically active or adult laan (i.e., a younger generation relative who could serve as a substitute for one's own child) is treated as the 
THAI ELDERLY

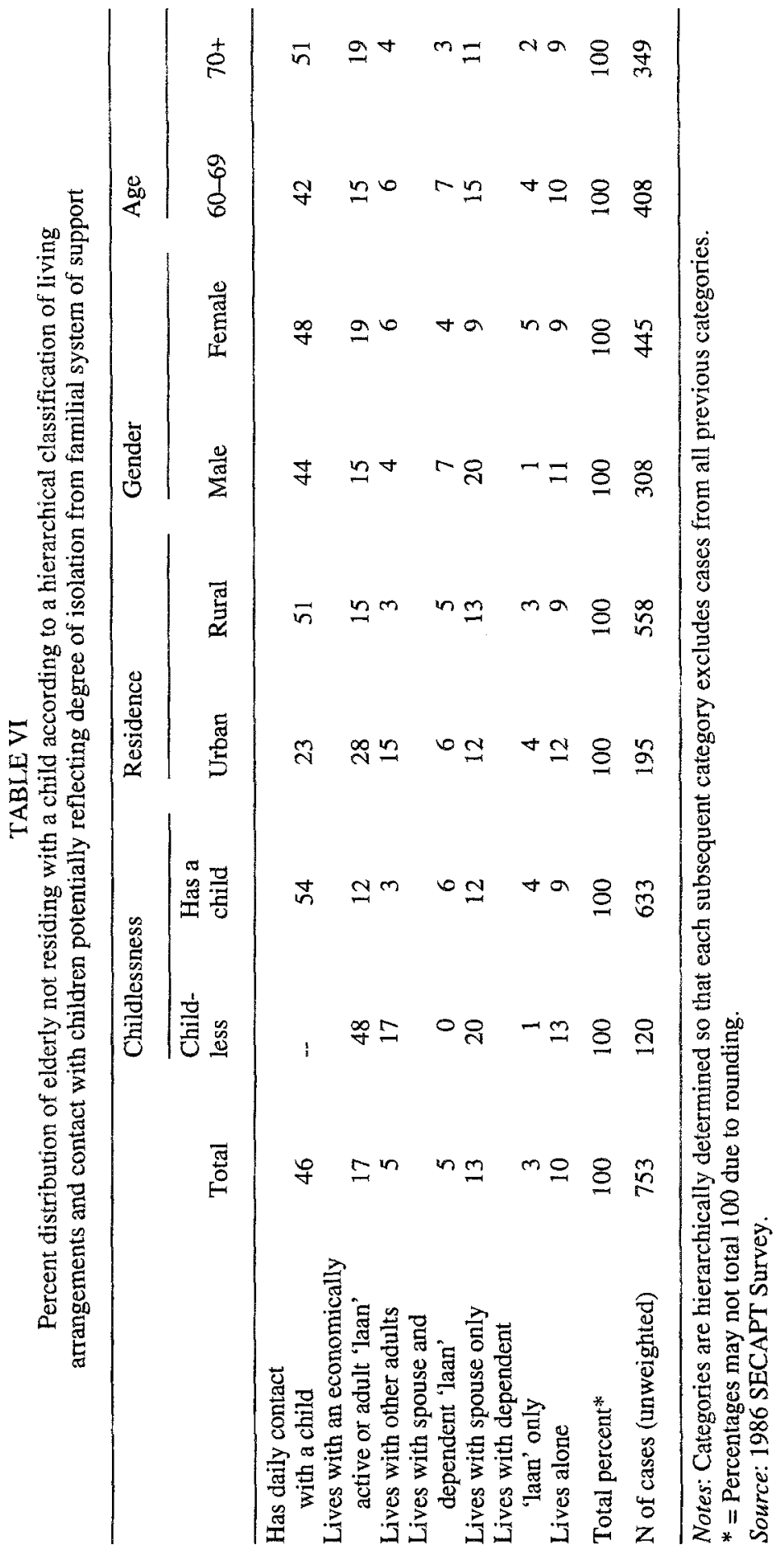


next closest equivalent to coresidence with a child and takes precedence over subsequent situations in the classification scheme. Since this category follows the 'daily contact' category, none of the $17 \%$ of non-coresident elderly in this category see a child of their own on a daily basis. Given that childless elderly by definition cannot be in contact with a child, a far greater share are eligible for this second category and indeed almost half live with an economically active and/or adult laan. The extent to which these laan serve as substitute children for the childless in providing support and care cannot be determined from the SECAPT data but for many this is likely to be the case. Even among noncoresident elderly parents there are some who do not see one or more of their children on a daily basis but live with an economically active and/or adult laan. Among non-coresident elderly overall, the proportion who fall in this category does not differ greatly by gender or age but is of greater importance among urban than rural residents making up in part for the lower proportions of urban elderly parents who have daily contact with a child.

The third situation specified consists of elderly who live with adults other than laan (and do not have daily contact with a child of their own). The adults in these cases are typically their siblings or other same generation relatives. This category accounts for only $5 \%$ of non-coresident elderly overall but represents a substantially greater proportion among childless elderly (17\%) and urban residents $(15 \%)$.

The remaining non-coresident elderly are divided into four categories, which might imply less involvement in support from children or family members (other than spouse) in terms of caregiving. These remaining elderly do not have daily contact with a child and have no economically active or adult person in the household other than possibly a spouse. ${ }^{11}$ Slightly less than a third of noncoresident elderly fall into these remaining four categories and this differs only modestly by childlessness status and residence. More pronounced differences are apparent by gender and age. Elderly males not in the previous categories are substantially more likely to be living with a spouse than are elderly women, reflecting the higher likelihood of wives surviving their husbands and probably higher remarriage rates among men. Many of these men are likely to have their needs for care-taking met by their wives, who tend to be younger and more socialized into the care-giving role. The older elderly are also less likely to fall into these categories, perhaps reflecting their greater need for care from other aduits.

Substantial proportions of non-coresident elderly falling in these last four categories receive material support, particularly money, from their children. For example, among the four last categories combined, i.e., non-coresident elderly who do not have daily contact with a child and do not live with an economically active and/or adult laan or other adults, two-thirds (67\%) of those who have at least one child report receiving money regularly from children (results not shown). Even when childless elderly are included, over half $(56 \%)$ of elderly in the last four categories say they receive regular monetary support from a child. Furthermore, the vast majority of elderly parents in these last four categories 
who are living with a dependent laan (whether with or without spouse) are particularly likely to report receiving money from a child, probably reflecting the fact that many are being reimbursed by their own children for taking care of the grandchildren. Focus group respondents mention that this practice is common for 'skip generation' households (Knodel, Saengtienchai, and Sittitrai 1992).

Non-coresident elderly in the four last categories are not characterized by perceptions of insufficient money, bad housing, loneliness or not being wanted to a greater extent than either other non-coresident elderly or coresident elderly. Their mean severity scores on most of these problems, calculated as described above, are not above average for elderly falling in these four categories (results not shown). This again suggests that living arrangements which deviate from the norm of coresidence with a child arise at least as often from a process that selfselects for the elderly's ability to live separately from children as from desertion of the elderly by their children. Quite likely a reasonable share of the elderly who are living separately from children are those who prefer to do so, at least at the particular phase of their life at the time of the survey. Moreover, once serious problems do arise, particularly ones which require a coresident caretaker, some will adjust their living arrangements to meet the new circumstances (see e.g., Caffrey 1992b). (Note the results presented above are cross-sectional in nature and thus cannot capture the dynamics involved in changes of living arrangements.)

\section{CONCLUSION}

Although the clear modal pattern of living arrangements characterizing the majority of elderly and the one with most normative support in Thailand is coresidence with an adult child, most of those who do not live with a child appear to be in situations in which the familial support system still operates. These alternative arrangements to coresidence with one's own child include living close enough to at least one child that daily contact is maintained, living with an economically active and/or adult younger generation relative who can serve as a substitute child, or living with other adult relations. Some elderly do appear to live in arrangements less integrated into the family support system such as living alone, only with their spouse, or only with dependent grandchildren or other young children and not having daily contact with one of their own children. This group, however, represents less than a third of noncoresident elderly and only a small fraction of elderly overall.

One underlying reason for the pervasiveness of family support and care is undoubtedly the lack of viable alternatives. Old age homes are rare and account for only a few thousand of Thailand's several million elderly. Other types of government social services are also minimal. While a social security act was put into effect in 1991 and the system is intended to eventually provide support payments to elderly, the actual implementation of this aspect is still sometime off in the future (Reinecke 1993). At the same time a sense of filial obligation 
and gratitude are deeply entrenched in Thai culture (Knodel, Saengtienchai, and Sittitrai 1992). Thus even when an elderly person's children might be prevented by circumstances from coresiding, alternative arrangements are often made by them for their parent's care (see e.g., Caffrey 1992b).

Although not common, there are some elderly Thais who have been deserted by their children and kin (Pramualratana 1990). Undoubtedly more common are cases who although coresident or in some living arrangement that links them to a potential care-giver are neglected to varying degrees (Pramualratana 1991; Caffrey 1992b.) Moreover, an unknown number of older persons may become either Buddhist monks or nuns and live at the temple in part because of the actual or anticipated lack of family support and care. Nevertheless, the overwhelming majority of elderly Thais are able to find at least a moderately satisfactory arrangement for living within the familial care system.

So far little solid evidence is available to indicate if and to what extent the living arrangements of elderly, and particularly coresidence with their children, have been changing in Thailand. The current high levels of coresidence, the fact that many non-coresident elderly are nevertheless in living arrangements that are in some way intertwined with children or other relatives, and the relatively common receipt of material support from children outside the household all suggest that the familial system of support for Thai elderly is still largely intact despite rapid and substantial social and economic change over recent decades. Whether this familial system of support will be undermined by the ongoing process of social change associated with economic development remains an open question. The results in the present study, however, suggest that declines in coresidence with children, should they be detected in the not-so-distant future, will not necessarily herald an erosion of the familial system of support. Careful scrutiny will be needed to determine how much such a trend reflects successful adaptations to changing circumstances within a broader familial network of care or even increased financial independence of the future generations of elderly leading to the purchase of greater privacy rather than a breakdown of the familial system of support.

\section{ACKNOWLEDGEMENTS}

The research on which this article is based was conducted as part of the project "The Comparative Study of the Elderly in Four Asian Countries" funded by the U.S. National Institute on Aging (Grant No. AG07673).

\section{NOTES}

1 Overall non-response was $25 \%$, almost half of which was attributable to hearing problems or illness. Thus the sample over-represents elderly who are in better physical and mental health. Although the sample was intended to be representative and self weighting, circumstances affecting fieldwork resulted in a disproportionately urban sample. A set of case-weights (normalized to 1.00) are applied to obtain representative results (Chayovan, Wongsith, and Saengtienchai 1988). 
2 Given that the elderly age range is defined as starting at age 60 in the SECAPT survey, a small proportion of the children of the elderly respondents, especially children of younger elderly males whose wives were often below age 60 , were non-economically active minors dependent entirely on their parents rather than providing support or sharing household expenses. Nevertheless, in $98 \%$ of the cases where an elderly respondent was coresident with a child, there was at least one child aged 18 or over in the household and in $99 \%$ of the cases there was a child aged 15 or over present.

${ }^{3}$ Note that spouses of elderly respondents, especially wives of men in their early sixties, are not necessarily elderly themselves although often this will be the case.

4 This situation where the elderly take care of a dependent grandchild whose parents are absent is sometimes referred to as the 'skip-generation' pattern (Hashimoto 1991). Qualitative evidence from focus group discussions in Thailand with both elderly and adult children confirm that this pattern is well recognized among Thais (Knodel, Saengtienchai, and Sittitrai 1992). Modifications of the skip-generation pattern can also occur among coresident elderly when some of the grandchildren present are children of absent siblings rather than of the coresident child of the elderly.

5 Frequently a copy of the household registration form that is in the possession of the respondent is used as the basis for the listing of household members that takes place during a survey interview.

6 If the dwelling units are simply functioning as separate bedrooms within a clearly delineated compound they could well have the same household registration number. But other more ambiguous cases or related clusters of dwelling units might be registered with different household numbers.

7 Since non-coresident parents necessarily have at least one non-coresident child, the comparison between coresident and non-coresident parents in Table III is restricted to parents with at least one non-coresident child. Among coresident parents, $8 \%$ have no non-coresident child.

8 Given that villages are typically rather small units (both in area and population) relative to towns or districts of Bangkok, differences in the way in which locality is defined in utban and rural areas is likely to bias the direction of differences in the opposite direction, i.e., to increase the proportion of elderly parents who have a non-coresident child in the same locality.

9 It appears that despite the reference in the question to "regular support", this was occasionally interpreted as including support provided as infrequently as once a year.

10 Although the question on types of support provided was open ended, it is not possible to distinguish provision of food from provision of clothes since they were coded as a single item. In cases where the elderly respondent indicated the child "provided everything", we assume that both food/clothes and money are involved.

11 Since these last four categories are mutually exclusive among themselves, their ordering with respect to the last four positions has no effect on their frequency. Their position as the last categories does effect all of them to the extent those with daily contact with children are preempted by the first category.

\section{REFERENCES}

Andrews, G. and M. Hennink 1992 The Circumstances and Contributions of Older Persons in Three Asian Countries: Preliminary Results of a Cross-national Study. Asia-Pacific Population Journal 7(3): 127-146.

Caffrey, R.A. 1992a Family Care of the Elderly in Northeast Thailand: Changing Patterns. Journal of Cross-Cultural Gerontology 7(2): 105-116.

Caffrey, R.A. $1992 \mathrm{~b}$ Caregiving to the Elderly in Northeast Thailand: Changing Patterns. Journal of Cross-Cultural Gerontology 7(2): 117-134.

Chayovan, N., M. Wongsith, and C. Saengtienchai 1988 Socio-Economic Consequences 
of the Ageing of the Population in Thailand: Survey Findings. Bangkok: Institute of Population Studies, Chulalongkorn University.

Chayovan, N., J. Knodel, and S. Siriboon 1990 Thailand's Elderly Population: A Demographic and Social Profile Based on Official Statistical Sources. Comparative Study of the Elderly in Asia, Research Report No. 90-2, Population Studies Center, University of Michigan.

Cowgill, D.O. 1972 The Role and Status of the Aged in Thailand. In Aging and Modernization. D.O. Cowgill and L.D. Holmes, eds. Pp. 91-101. New York: Appleton-Century-Crofts.

Hashimoto, A. 1991 Living Arrangements of the Aged in Seven Developing Countries: A Preliminary Analysis. Journal of Cross-Cultural Gerontology 6: 359-381.

Hashimoto, A., H. Kendig and L.C. Coppard 1992 Family Support to the Elderly in International Perspective. In Family Support for the Elderly: The International Experience. H.L. Kendig, A. Hashimoto, and L.C. Coppard, eds. Pp. 293-308. New York: Oxford University Press.

Knodel, J., C. Saengtienchai, and W. Sittitrai 1992 The Living Arrangements of Elderly in Thailand: Views of the Populace. Comparative Study of the Elderly in Asia, Research Report No. 92-20, Population Studies Center, University of Michigan.

Knodel, J., N. Chayovan, and S. Siriboon 1992 The Familial Support System of Thai Elderly: An Overview. Asia-Pacific Population Journal 7(3): 105-126.

Knodel, J., N. Chayovan, and S. Siriboon 1993 Familial Support and the Life Course of Thai Elderly and Their Children. In Aging and Generational Relations over the Life Course: A Historical and Cross-cultural Perspective. T. Hareven, ed. Berlin: Walter de Gruyter \& Co. (forthcoming).

Pichyangkura, C. and M. Singhajend 1991 Thailand National Review on the Elderly. Paper Presented at the Workshop on Population Aging, ESCAP, Bangkok, Thailand, 15-22 July 1991.

Pramualratana, A. 1990 Support Systems of the Old in a Rural Community in Thailand. Ph.D. Thesis. Australian National University, Canberra, Australia.

Pramualratana, A. 1991 Consensual Neglect: An Interpretive Analysis of Adult Children's Support to the Old in Rural Thailand. Paper presented at the Annual Meeting of the Population Association of America, Washington D.C., March 21-23, 1991.

Reinecke, G. 1993 Social Security in Thailand: Political Decisions and Distributional Impact. Report on the ASA project Social Security in Thailand. Unpublished paper.

Rubinstein, R. 1987 Childless Elderly: Theoretical Perspectives and Practical Concerns. In Journal of Cross-Cultural Gerontology 2(1): 1-14.

Sung, K. 1991 Family-Centered Informal Support Networks of Korean Elderly: The Resistance of Cultural Traditions. Journal of Cross-Cultural Gerontology 6(4): $431-447$.

Tuchrello, W.P. 1989 The Society and Its Environment. In Thailand: A Country Study, Sixth Edition (Area Handbook Series). B.L. LePoer, ed. Pp. 55-120. Washington: U.S. Government Printing Office.

Wongsith, M. 1990 Attitudes Towards Family Values in Thai Society. Paper presented at the Nihon University International Symposium on Family and the Contemporary Japanese Culture: An International Perspective, Tokyo, October 20-24, 1990.

Siriwan Siriboon

Institute of Population Studies

Chulalongkorn University

Bangkok, Thailand
John Knodel

Population Studies Center University of Michigan Ann Arbor, Michigan, U.S.A. 